\title{
LH- and FSH-Secreting Pituitary Adenoma in a Postmenopausal Woman
}

\author{
NAOKi HATTORI, TAKASHi ISHIHARA, Kunisaburo MORIDERA, \\ Katsuji IKEKUBO*, Megumu HINO*, Yasuhiko SAIKI*and \\ Hiroyuki KURAHACHI \\ Department of Endocrinology and ${ }^{*}$ Department of Nuclear \\ Medicine, Kobe City General Hospital, Kobe 650, Japan
}

\begin{abstract}
Gonadotropin secreting pituitary adenomas have been reported with increasing frequency in men, but they are still rarely recognized in women. We report a 52-year-old postmenopausal woman with LH- and FSH-secreting pituitary adenoma. She had increased LH $(37.0 \pm 13.7 \mathrm{IU} / l)(\mathrm{mean} \pm \mathrm{SD})$ and FSH $(109.9 \pm 26.7 \mathrm{IU} / l)$ but these concentrations were within normal ranges in 80 postmenopausal women (LH: $29.7 \pm 18.3 \mathrm{IU} / l, \mathrm{FSH}: 104.0 \pm 43.9 \mathrm{IU} / l$ ). The administration of GnRH and conjugated estrogen resulted in normal response of $\mathrm{LH}$ and $\mathrm{FSH}$. No abnormal response of gonadotropin to TRH and bromocriptine was observed. After transsphenoidal adenomectomy both LH and FSH decreased (LH: $11.1 \pm 4.2 \mathrm{IU} / l$, FSH: 37.0 $\pm 9.6 \mathrm{IU} / l$ ). An immunocytochemical study revealed that the adenoma cells synthesize both LH and FSH. The rarity of gonadotropin secreting pituitary adenomas in women could be the result of greater difficulty in recognition due to an increase in serum gonadotropin in postmenopausal women.
\end{abstract}

Key words: LH, FSH, Pituitary adenoma, Menopause.

(Endocrinol Japon 38: 393-396, 1991)

GONADOTROPIN-secreting pituitary adenomas have been reported relatively infrequently [1, 2]. The diagnosis is facilitated in vivo by increases in the circulating gonadotropin levels. As a result, most of the patients are males. In middle-aged females with pituitary adenomas and increased gonadotropin, the distinction between gonadotropin-secreting pituitary adenoma and nonfunctioning pituitary adenoma associated with normal postmenopausal serum concentrations of gonadotropins is difficult to make. In addition, it is not clear whether gonadotropin levels change during postmenopause. If serum gonadotropin increases with age as demonstrated in men [3, 4], the determination of gonadotropin levels may be useless in the follow-up. We report a postmeno-

Received: February 8, 1991

Accepted: July 6, 1991

Correspondence to: Dr. Naoki HATTORI, Department of Endocrinology, Kobe City General Hospital, 4-6 Minatojima Nakamachi, Chuo-ku, Kobe 650, Japan. pausal woman with LH- and FSH-secreting pituitary adenoma and demonstrate the relationship between age and gonadotropin levels in postmenopausal women.

\section{Case Report}

A 52-year-old woman was referred to our hospital for the evaluation of a pituitary tumor. She had experienced nasal bleeding several times during the previous 3 months and a pituitary tumor was incidentally discovered by head CT. She noticed blurred vision for about two weeks prior to admission. She had 2 children 28 and 31 years old. She noticed amenorrhea five months ago after irregular menstrual cycles for about a year. On physical examination she was a normally developed woman $158 \mathrm{~cm}$ tall weighing $61.5 \mathrm{~kg}$. Pubic and axillary hair were normal and there was no evidence of galactorrhea. Ophthalmological 
studies revealed a small temporal defect in the visual field of the right eye.

Blood was taken in the morning after an overnight fast. Serum LH and FSH levels were determined by immunoradiometric assay (Daiichi Radioisotope, Tokyo, Japan) with reference standards of 1st IRP LH 68/40 for LH and 2nd IRP HPG 78/549 for FSH. Monoclonal antibodies were used for solid and labeled antibodies. The cross reactivity of $\mathrm{FSH}$ in $\mathrm{LH}$ assay was less than $2 \%$ and that of LH in FSH assay was negligible. Alpha subunit did not cross-react in either assay. Successive adjacent serial sections of the tumor were treated with peroxidase labeled anti-LH and FSH polyclonal antibodies (Dako, Kyoto, Japan). The cross reactivity of FSH in the LH assay was less than 5\% and that of LH in the FSH assay was less than $10 \%$. Serum PRL levels were measured by immunoradiometric assay (Dainabot, Tokyo, Japan) with a reference standard of NIH VLS\#4.

Routine blood and urine chemical determinations were normal. Basal serum $\mathrm{LH}$ and FSH were increased (LH: $37.0 \pm 13.7 \mathrm{IU} / /$, FSH: 109.9 \pm 26.7 $\mathrm{IU} / l)$ (mean $\pm \mathrm{SD})$ but these were within normal ranges in 80 postmenopausal women aged from 50 to 82 yr (LH: $29.7 \pm 18.3 \mathrm{IU} / /$, FSH: $104.0 \pm 43.9$ $\mathrm{IU} / l)$. No significant correlations were found between age and gonadotropin levels in postmenopausal women (LH: $r=-0.06$ NS, FSH: $r=0.21$ NS). Serum PRL was increased $(44.4 \pm 5.6 \mu \mathrm{g} / l)$ and serum estradiol was less than $10 \mathrm{pg} / \mathrm{ml}$. Results of loading tests are shown in Table 1. GnRH (100 $\mu \mathrm{g}$ i.v.) elicited a normal increase in $\mathrm{LH}$ and $\mathrm{FSH}$

Table 1. Endocrine function tests

\begin{tabular}{llrr}
\hline Test & Hormone & Basal & Peak \\
\hline TRH & PRL $(\mu \mathrm{g} / l)$ & 45.1 & 184.3 \\
& TSH $(\mathrm{mU} / l)$ & 2.2 & 15.6 \\
& LH $(\mathrm{IU} / l)$ & 26.9 & 30.3 \\
& FSH $(\mathrm{IU} / l)$ & 83.9 & 100.3 \\
GnRH & LH $(\mathrm{IU} / l)$ & 33.0 & 94.3 \\
& FSH $(\mathrm{IU} / l)$ & 100.0 & 170.4 \\
ITT & Cortisol $(\mu \mathrm{g} / \mathrm{d} l)$ & 6.0 & 27.4 \\
& GH $(\mu \mathrm{g} / l)$ & $<1.5$ & 25.0 \\
& & Basal & Nadir \\
Bromocriptine & PRL $(\mu \mathrm{g} / l)$ & 37.2 & 4.8 \\
& LH $(\mathrm{IU} / l)$ & 48.8 & 43.9 \\
& FSH $(\mathrm{IU} / l)$ & 122.7 & 120.2 \\
Estrogen & LH $(\mathrm{IU} / l)$ & 56.4 & 17.1 \\
& FSH $(\mathrm{IU} / l)$ & 155.8 & 60.4 \\
\hline
\end{tabular}

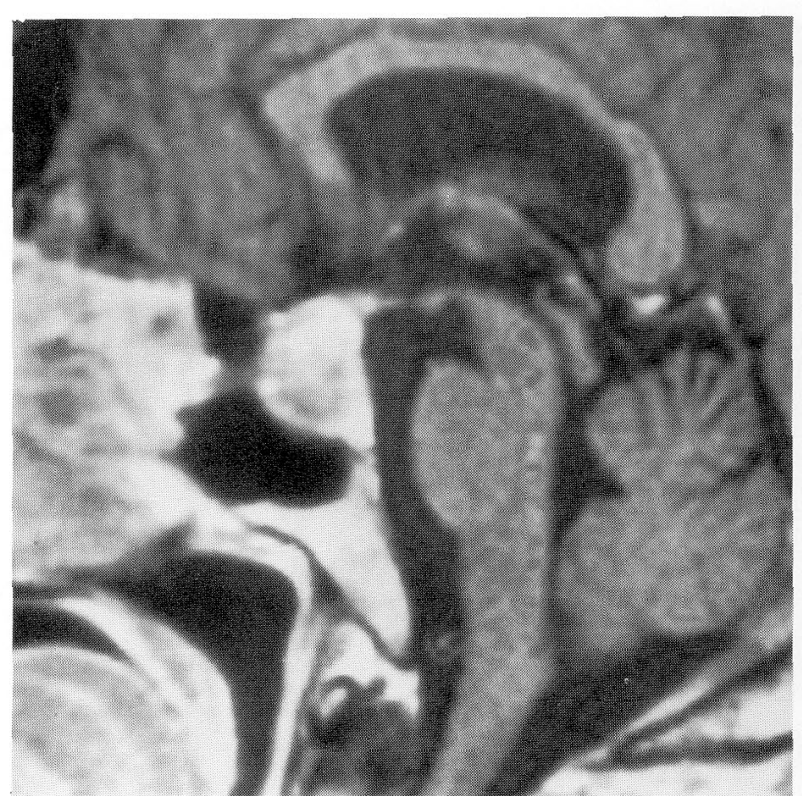

Fig. 1. Postcontrast saggital T1-weighted MR image shows a pituitary adenoma with suprasellar extension.
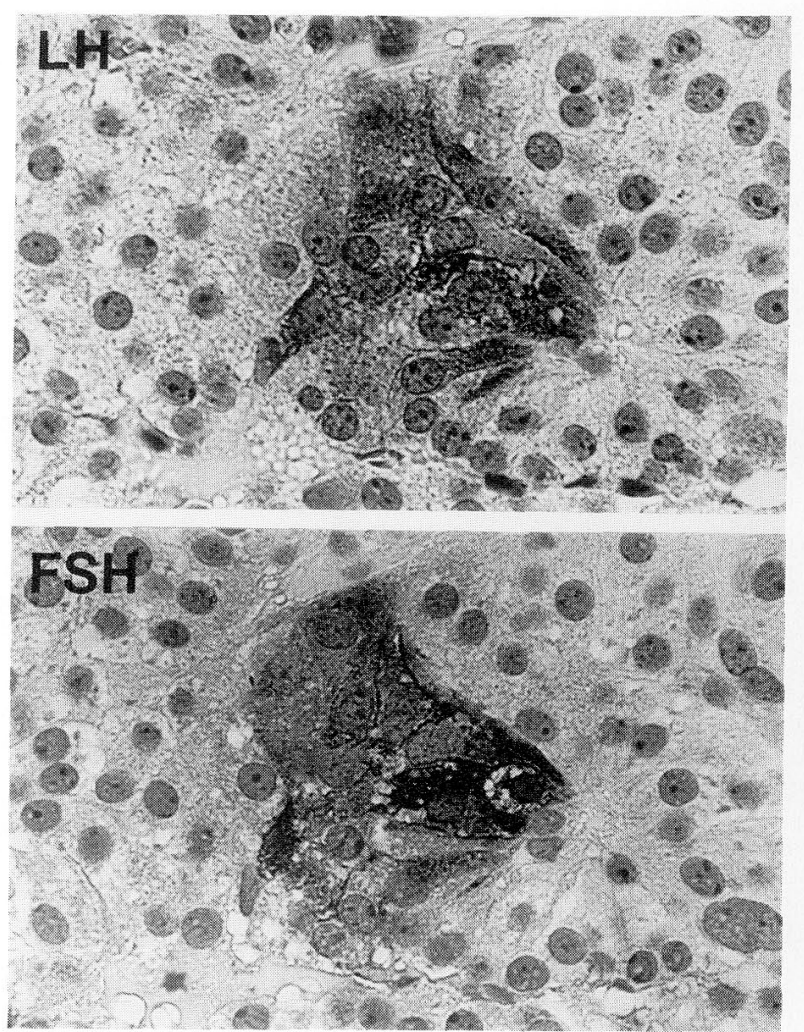

Fig. 2. Immunostaining for LH (above) and FSH (below). Note that both hormones are positive in the adjacent adenoma cells with morphological similarity. 


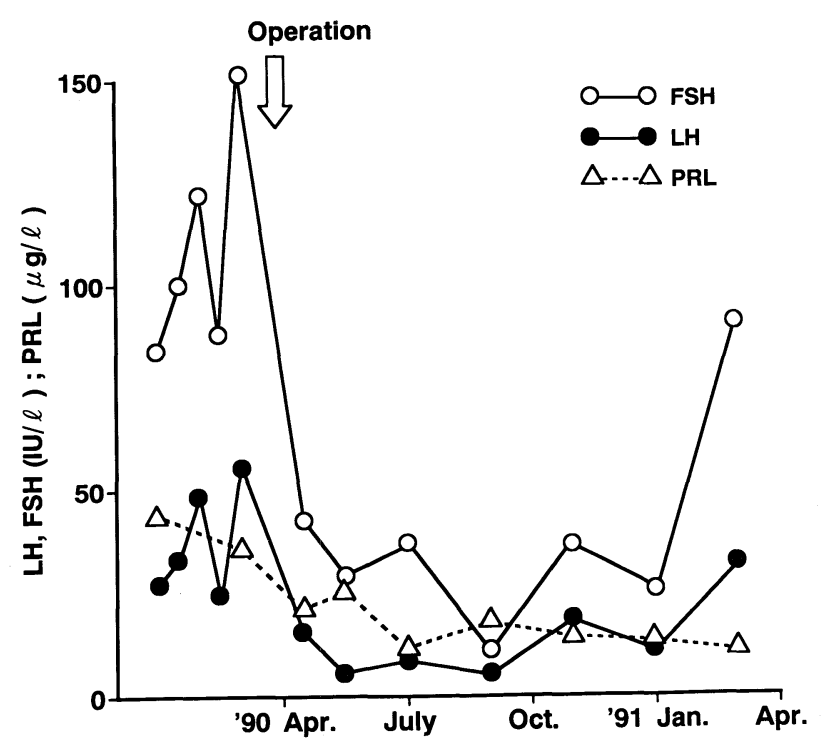

Fig. 3. Changes in serum LH, FSH and PRL levels before and after transsphenoidal adenomectomy in a postmenopausal woman with LH- and FSH-secreting pituitary adenoma.

levels. Administration of conjugated estrogen (Premarin, Toyo Johzo, $20 \mathrm{mg}$ i.v.) resulted in normal suppression of $\mathrm{LH}$ and FSH during $72 \mathrm{~h}$. No abnormal response of gonadotropins to TRH (500 $\mu \mathrm{g}$ i.v.) or bromocriptine (5 $\mathrm{mg}$ p.o.) was observed. Skull X-ray, head CT and MRI (Fig. 1) were consistent with a pituitary adenoma with suprasellar extension.

Transsphenoidal pituitary adenomectomy was performed and most of the pituitary tumor was removed, although a residual tumor surrounding the left carotid artery remained. The adenoma cells showed positive immunostaining for $\mathrm{LH}$ and FSH antisera but not for prolactin. The immunostaining cells were arranged in clusters and dispersed in the tumor. When comparing adjacent serial sections immunostained with anti-LH and FSH, we found that both hormones were positive in the adjacent cells with morphological similarity (Fig. 2). Immediately after surgery, the basal levels of $\mathrm{LH}$ and FSH decreased (LH: $11.1 \pm 4.2 \mathrm{IU} / l$, FSH: $37.0 \pm 9.6 \mathrm{IU} / l)$ but had a tendency to increase one year later. (Fig. 3).

\section{Discussion}

Gonadotropin-secreting pituitary adenomas are uncommon, and, in particular, tumors which secrete both LH and FSH have been reported by only a few investigators [5-7]. However, recent studies have shown that most clinically nonfunctioning pituitary adenomas contain or release gonadotropins in vitro $[8,9]$. This discrepancy can be explained by low levels of hormone release [9].

We had a postmenopausal woman with increased gonadotropin and a pituitary adenoma, and were confronted with 1) whether an increased gonadotropin concentration was due to the pituitary adenoma or to postmenopause, and 2) whether the determination of gonadotropin levels would be useful as a tumor marker in the follow-up if she had a gonadotropin-secreting pituitary adenoma. Her LH and FSH levels were within the normal range for postmenopausal women, and could not be useful a differential diagnosis of gonadotropin secreting pituitary adenoma and nonfunctioning adenoma. An abnormal response of gonadotropins to TRH and/or dopamine was reported in some patients with gonadotropin secreting pituitary adenomas $[10,11]$. We did not, however, observe these abnormalities. Gonadotropin responses to GnRH and estrogen in patients with gonadotropin secreting pituitary adenomas are varied: administration of $\mathrm{GnRH}$ causes exaggerated, normal or subnormal responses of gonadotropins and administration of estrogen results in suppression, stimulation or no change in gonadotropin levels [7]. Our patient showed normal gonadotropin responses to GnRH and estrogen, suggesting that hypothalamic regulation is preserved. Only immunocytochemistry was useful, revealing that immunostaining for $\mathrm{LH}$ and FSH were localized in the tumorous cell cytoplasm and that the immunostaining cells were arranged in clusters and dispersed in the tumor. The immunostaining of adjacent serial sections with LH and FSH showed that both hormones were positive in the adjacent cells which were morphologically similar, suggesting that the tumor synthesized both LH and FSH simultaneously.

Since we did not find an increase in LH and FSH levels with advancing age during postmenopause, which was in agreement with a previous report [12], the measurement of gonadotropin levels could be used for detecting re-growth of the adenoma even in a postmenopausal woman. However, it should be remembered that gonadotropin levels fluctuate and basal hormone levels do not necessarily represent the bulk of the tumor as shown by the preoperative data. 


\section{References}

1. Snyder PJ (1985) Gonadotroph cell adenomas of the pituitary. Endocr Rev 6: 552-563.

2. Trouillas J, Girod C, Sassolas G, Claustrat B, Lhéritier M, Dubois MP, Goutelle A (1981) Human pituitary gonadotropic adenoma; histological, immunocytochemical, and ultrastructural and hormonal studies in eight cases. $J$ Path 135: 315-336.

3. Blackman MR, Tsitouras PD, Harman SM (1987) Reproductive hormones in aging men. III. Basal and LHRH-stimulated serum concentrations of the common alpha-subunit of the glycoprotein hormones. J Gerontol 42: 476-481.

4. Deslypere JP, Vermeulen A (1984) Leydig cell function in normal men: effect of age, lifestyle, residence, diet, and activity. J Clin Endocrinol Metab 59: 955-962.

5. Snyder PJ, Sterling FH (1976) Hypersecretion of LH and FSH by a pituitary adenoma. $J$ Clin Endocrinol Metab 42: 544-550.

6. Demura R, Kubo O, Demura H, Shizume K (1977) FSH and LH secreting pituitary adenoma. J Clin Endocrinol Metab 45: 653-657.

7. Nicolis GL, Modhi G, Gabrilove JL (1982) Gonadotropin producing pituitary adenomas. A case report and review of the literature. Mt Sinai J Med 49: 297-304.

8. Kwekkeboom DJ, De Jong FH, Lamberts SWJ
(1989) Gonadotropin release by clinically nonfunctioning and gonadotroph pituitary adenomas in vivo and in vitro: relation to sex and effects of thyrotropin-releasing hormone, gonadotropinreleasing hormone, and bromocriptine. J Clin Endocrinol Metab 68: 1128-1135.

9. Yamada S, Asa SL, Kovacs K, Muller P, Smyth HS (1989) Analysis of hormone secretion by clinically nonfunctioning human pituitary adenomas using the reverse hemolytic plaque assay. J Clin Endocrinol Metab 68: 73-80.

10. Snyder PJ, Muzyka R, Johnson J, Utiger RD (1980) Thyrotropin-releasing hormone provokes abnormal follicle stimulating hormone (FSH) and lutenizing hormone responses in men who have pituitary adenomas and FSH hypersecretion. J Clin Endocrinol Metab 51: 744-748.

11. Berezin M, Olchovsky D, Pines A, Tadmor R, Lunenfeld B (1984). Reduction of folliclestimulating hormone (FSH) secretion in FSHproducing pituitary adenoma by bromocriptine. $J$ Clin Endocrinol Metab 59: 1220-1223.

12. Kwekkeboom DJ, De Jong FH, Van Hemert AM, Vandenbroucke JP, Valkenburg HA, Lamberts SWJ (1990) Serum gonadotropins and $\alpha$-subunit decline in aging normal postmenopausal women. $J$ Clin Endocrinol Metab 70: 944-950. 